\title{
The Roles of CSR and Marketing Ethics in FMCG Company's Reputation During the Covid-19 Pandemic
}

\author{
Miharni Tjokrosaputro ${ }^{1 *}$
}

\author{
${ }^{1}$ Faculty of Economics, Universitas Tarumanagara, Jakarta, Indonesia \\ *Corresponding author. Email: miharnit@fe.untar.ac.id
}

\begin{abstract}
This study aimed to reveal whether Corporate Social Responsibility (CSR) and marketing ethics have certain roles in the reputation of Fast-Moving Consumer Goods (FMCG) Company during the Covid-19 pandemic. This study used survey method by collecting data through questionnaire. The respondents in this study were 128 consumers of FMCG and acquired by using the convenience sampling technique and the data was then analysed using SPSS. The result of this study showed that CSR and marketing ethics positively and significantly affect the FMCG company's reputation, either partially or simultaneously during this Covid-19 pandemic.
\end{abstract}

Keywords: CSR, Marketing Ethics, Company's Reputation, FMCG

\section{INTRODUCTION}

In the beginning of 2020, the Covid-19 pandemic occured all over the world including in Indonesia. This pandemic causes many victims, resulting changes in many things and causing economic resesion in many countries. Many researchers describe the world's condition during this pandemic as the "Black Swan Event" [1], whereas many people are shocked by a phenomenon, and then followed by cultural changes in community.

The crisis caused by this Covid-19 pandemic creates challenges to many parties, including companies and organizations. Neverthless, there are various responses from companies in facing this crisis. There are some companies acting positively by supporting the impacted community through CSR activities, while others are taking short-term advantages during this pandemic unethically. Thus, the researcher in this study is interested in observing the roles of CSR and marketing ethics in FMCG company's reputation during the Covid-19 pandemic.

Recently, CSR has become one of many issues highlighted by various media. In recent decade, the number of companies that realize the importance of CSR has been increasing. This phenomenon can be seen in the KPMG report in 2017, in which $93 \%$ companies among the Top250 biggest companies in the world reported about the CSR activities that had been conducted.

This study intended to observe the consumers' perception on CSR activities conducted by companies related to the Covid-19 pandemic. Moreover, this study would discuss about consumers' trust on how responsible a company socially as a reaction to CSR that had been conducted, or commonly known as Consumers' Trust in CSR [4].

In some previous research, CSR is assumed as one of the key attributes that determine the company's reputation [5]. Moreover, the research conducted by [6] and [7] showed that CSR has become an important element of company's reputation during the crisis. Hence, this study will connect between CSR and company's reputation viewed from the consumers' perception.

Prior to this pandemic era, there were many issues that appeared related to marketing ethics. This caused disadvantages to the stakeholders. There were some cases about marketing ethics in various media, such as the case of Facebook, Google, and other companies that misused the consumers' data for their own interests. Moreover, Novartis as a pharmacy company encouraged phycisians to use their products in order to increase their sales [2]. Thus, during this Covid 19 pandemic, there are various issues related to marketing ethics due to the scarcity of various goods and the change in community's lifestyle.

This study was conducted due to the limited amount and scope of previous studies discussing about marketing ethics, especially from the normative side [3]. Besides, the implementation of marketing ethics has not acquired sufficient attention in business practice. This phenomenon aroused the researcher's curiosity to study more deeply about the effect of marketing ethics on company's reputation.

Consumer's of PT. Unilever Indonesia (next will be mentioned as Unilever) was selected as sample, because Unilever is a well-known company in producing FastMoving Consumer Goods (FMCG) in Indonesia since 1933. Nowadays, Unilever owns 42 FMCG brands and nine factories located in Cikarang (West Java) and Rungkut (East Java). Besides, Unilever tries to provide the benefits to community and the surroundings through their products and campaigns, so that the company's mission to popularize sustainable living (eco-friendly and providing social benefits) can be achieved. During the Covid-19 pandemic, Unilever has provided various supports in form of hand sanitizer, soap, house-cleaning products, as well as the education about hygiene to community. Moreover, Unilever conducted the "Clean-Mask Movement" toward 100.000 
masks, "Clean-School Movement" and "CleanEnvironment Movement" by collaborating with The Indonesia Ministry of Health and related institutions. Meanwhile, to internal employees, Unilever has been implementing the "Work-from-Home" activities and highlevel of health protocol [8].

Based on the explanation above, the researcher was interested to observe the phenomenon by selecting the title "The role of CSR and marketing ethics in FMCG company's reputation". This study was expected to provide the clarity on the role of CSR and marketing ethics in FMCG company's reputation. In addition, this study was expected to provide contribution to practitioners about the importance of CSR and marketing ethics conducted by companies to consumers, and their effects on company's reputation.

This study was meant to enrich the studies about the relationship among CSR, marketing ethics, and company's reputation, due to there are some inconsistencies in several research about such relationship. Such inconsistencies occur in form of some opinions that consumer behavior is more affected by company's marketing ethics [9]. Meanwhile, other researchers mentioned that consumer behavior affected by ethics and CSR simultaneously have positive impact on company's reputation [10] and [11].

Practical benefits from this study is in form of an input for FMCG producers about the role of CSR and marketing ethics in company's reputation, during the Covid-19 pandemic.

\section{LITERATURE REVIEW}

This study is based on the Resource Based Theory (next will be mentioned as RBT). RBT views the company's reputation as one of the invisible resources, which is important in achieving simultaneous competitive advantage for the company [12].

\section{1. $C S R$}

At present days, CSR becomes a commonly-used term in business [17]. Kotler and Lee [18] defined CSR as a company's commitment to increase the community's welfare through business practice and wise contribution of the company's resources.

Jamali [19] stated that there are four kinds of socialresponsibility included in the CSR, which are the responsibilities in economic, law, ethics, and philantrophy. In facing the crisis, Tucker and Melewar [20] stated that CSR becomes an important element of reputation.

There are six forms of CSR activities viewed from the perspective of the company and consumers [18]. The first, is fund-raising activities or equivalent activities conducted by the company to increase the community's awareness and attention on social issues. The second, is the company's commitment to contribute or donate some percentage of income for certain events or prroblems. The third, is company's support toward behavioral change in order to improve public health, safety, environment or welfare. The fourth, is direct contribution of the company in donating its fund or equivalent for charity or certain events. The fifth, is the support or encouragement from the company to the employees and business partners to be volunteers I local community organization and certain events. And the last, is business practice that is conducted wisely by the company to support and solve social issues which aims to increase community's welfare and environment protection.

The CSR conducted during the Covid-19 pandemic will establish a stronger relationship between company and consumers, as well as public, related to the efforts to fight the virus together. Consumers will be proud of the company that can support its employees and donate funds and equipments during the crisis. The bond established between the company and its consumers during this crisis, can be more meaningful and long-lasting compared to the CSR conducted out of the global crisis. Hence, the Covid-19 pandemic can be an opportunity for the company to actively involve in the community by its own CSR strategy and agenda [1].

\subsection{Marketing Ethics}

Marketing ethics is a part of business ethics [13] which becomes an ethical measure in marketing-mix, political marketing, and social marketing [14]. Recently, the role of marketing ethics becomes more important in marketing practice [14].

In this sudy, marketing ethics is defined as a standard of behavior and moral decision applied in marketing practice [15], whereas marketing ethics refers to moral challenge faced by marketing practitioners in their routine jobs and they have to determine the action which is morally right / good or wrong / bad [13]. The role of marketing ethics for consumers is providing information to community about relevant norms and values, as well as enhancing its implementation in marketing [16].

\subsection{Company's Reputation}

There are several definitions on company's reputation. Walsh dan Beatty [21] defined it from the perspective of consumers, whereas company's reputation is viewed as a consumers' overall evaluation of the company based on their reactions to the products, services, communication, activities, interaction with the company or its representatives (such as employees, management or other consumers) and/or company's activities. Neverthless, Reputation Institute through RepTrack $\odot$ measures the emotional and rational aspect of company's reputation, among others are leadership, performance, workplace, governance, and citizenship [22].

Besides, Walsh and Beatty [21] argued that the dimensions used to measure the company's reputation from consumers' perspective are consumers' orientation, good employees, an 
eligible and strong company in marketing, product or service quality, and attention to CSR and the environment. Moreover, Lange, Lee, and Ye [23] stated that reputation also includes the company's conceptualization of being known, being known for something, and generalized favorability. A company as being known, is public awareness or distinguished view toward the company in the collective perspective. A company as being known for something, is the expected perception of company's product or relevant behavior toward specific market interest. A company, that has generalized favorability, is the perception or assumption about the organization entirely as good, attractive, and eligible.

\subsection{The Relationship between CSR and Company's Reputation}

The study conducted by He [1] showed that CSR done in crisis era i.e., during the Covid-19 pandemic, can build a reputation that the company has empathy and keeps struggling to fight the virus. The positive reputation built is commonly related to the company's marketing performance, which is attached to the inability of competitors to imitate such reputation [24]. Besides, several studies mentioned that CSR has positive effect on community and stakeholders' assessment toward the company in general [21]. Moreover, He [1] mentioned that the CSR conducted during this Covid-19 pandemic will have positive effect on company's reputation.

\subsection{The Relationship between Marketing Ethics and Company's Reputation}

The implementation of marketing ethics often becomes the subject of argumentation in a company when being faced to the organization system [25]. Neverthless, the implementation of marketing ethics is strongly related to the marketing strategy conducted by the company, which is integrated in the strategy, that finally will enhance the company's reputation toward competitive advantage [26] [27]. In the study conducted by Sasse \& Trahan [28], marketing ethics is proven to be able to influence consumers' attitude toward the company, one of which can affect the company's reputation.

\subsection{The Relationship Among CSR, Marketing Ethics, and Company's Reputation}

In the study conducted by Pirsch, Gupta, anddan Grau [11], consumers' attitude affected by ethics and CSR simultaneously can positively affect company's reputation. Besides, Altinbasak [27] showed that CSR and marketing ethics positively and significantly affect the company's reputation in general.

\section{PREVIOUS RESEARCH}

In several previous research, the CSR activities conducted by reputable companies can increase their reputation [28]. Furthermore, the research conducted by He [1] about CSR which was conducted by companies during the Covid-19 pandemic, showed that the company's marketing efforts should pay attention to the CSR in order to increase the reputation, especially during this crisis era.

Research by Sassee \&Trahan [28] also concerns about the role of marketing ethics in building the company's reputation. Besides, CSR and marketing ethics also positively affect the company's reputation [27].

Neverthless, other studies also showed that consumers' attitude affected by CSR and marketing ethics positively affect the company's reputation [11] [30].

\section{RESEARCH MODEL}

This study tested the relationship among CSR, marketing ethics, and company's reputation. The relationship between each construct is explained in the research model as follow (Figure 1). Data analysis was started by testing the relationship between the variable of CSR and company's reputation, and then followed by testing that of the marketing ethics and company's reputation, and finally by testing the effects of CSR and marketing ethics simultaneously on company's reputation.

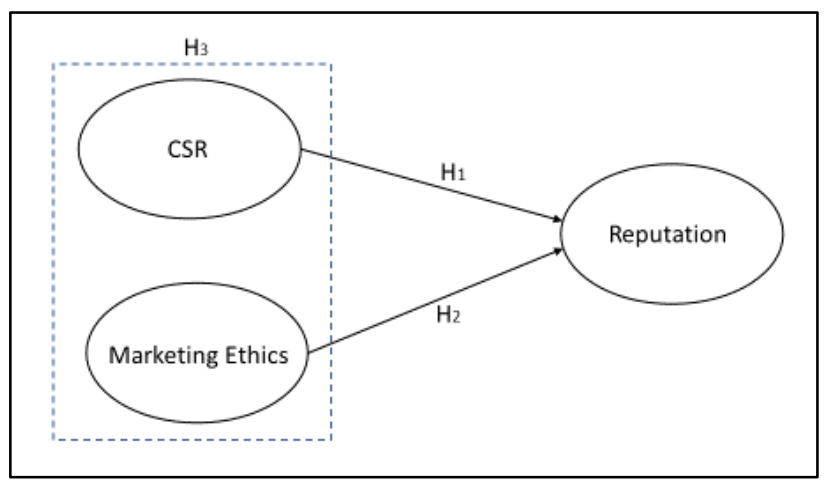

Figure 1. Research Model

This study concerns on how the CSR activities conducted by company and marketing ethics can affect the FMCG company's reputation during the Covid-19 pandemic. All variables were measured from the perspective of consumers. Below are the hypotheses tested in this study. $\mathrm{H}_{1}$ : CSR has a positive and significant effect on Company's Reputation.

$\mathrm{H}_{2}$ : Marketing Ethics has a positive and significant effect on Company's Reputation.

$\mathrm{H}_{3}$ : CSR and Marketing Ethics simultaneously have positive and significant effects on Company's Reputation. 


\section{RESEARCH METHOD}

The sampling method used in this study was convenience sampling. The questionnaire was distributed to respondents through Google Form. The sample size in this study consist of 145 respondents, but only 128 respondents could be processed further. Among the respondents, $41.4 \%$ was the consumers of Pepsodent / Close-Up tooth paste, $20.3 \%$ was the consumers of Lifebuoy / Lux soap, $23.4 \%$ was the consumers of Clear / Tressemme shampoo, and the rest was the consumers of body treatment and beverages products of Unilever.

About the respondents' demography, $51.6 \%$ was male, and the remaining $48.4 \%$ was female. Respondents between the age of $17-22$ y/o was 114 persons (89\%) with the occupation as undergraduate students.

The variables' operasionalization to measure CSR used 5 indicators adapted from Du, Bhattacharya, and Sen [4] and Walsh and Beatty [21] using 5-point Likert scale. To measure Marketing Ethics, 5 indicators adapted from Brunk [9], and Vittel, Rallapalli, and Singhapakdi [31] were used with 5-point Liekrt scale. And to measure company's reputation, 8 indicators adapted from Walsh and Beatty [21] were used with 5-point Likert scale.

\section{RESULTS AND DISCUSSIONS}

According to the results of KMO and Bartlet test, the significance value of 0.0000 shows that the sampling size was sufficient to conduct the factor analysis. Besides, the results in rotated component matriks shows the factorloading for $\mathrm{CSR}_{2}, \mathrm{CSR}_{5}, \mathrm{ME}_{2}, \mathrm{ME}_{5}, \mathrm{R}_{1}, \mathrm{R}_{4}$, and $\mathrm{R}_{8}$ were less than 0.6. Hence, such indicators were not used in the next data processing.

Tabel 1. Validity and Reliability

\begin{tabular}{|c|c|c|c|}
\hline \multirow[b]{2}{*}{ Variable } & \multirow[b]{2}{*}{ Indicator } & Validity & Reliability \\
\hline & & 1 & $\begin{array}{c}\text { Cronbach's } \\
\text { Alpha }\end{array}$ \\
\hline \multirow[t]{5}{*}{ CSR } & $\mathrm{CSR}_{1}$ & 0.784 & \multirow{5}{*}{0.742} \\
\hline & $\mathrm{CSR}_{2}$ & 0.519 & \\
\hline & $\mathrm{CSR}_{3}$ & 0.729 & \\
\hline & $\mathrm{CSR}_{4}$ & 0.693 & \\
\hline & $\mathrm{CSR}_{5}$ & 0.542 & \\
\hline \multirow[t]{5}{*}{ Marketing Ethics } & $\mathrm{ME}_{1}$ & 0.675 & \multirow{5}{*}{0.679} \\
\hline & $\mathrm{ME}_{2}$ & 0.488 & \\
\hline & $\mathrm{ME}_{3}$ & 0.788 & \\
\hline & $\mathrm{ME}_{4}$ & 0.636 & \\
\hline & $\mathrm{ME}_{5}$ & 0.487 & \\
\hline Reputation & $\mathrm{R}_{1}$ & 0.486 & 0.724 \\
\hline
\end{tabular}

\begin{tabular}{|l|l|l|}
\hline & $\mathrm{R}_{2}$ & 0.610 \\
\hline & $\mathrm{R}_{3}$ & 0.663 \\
\hline & $\mathrm{R}_{4}$ & 0.468 \\
\hline & $\mathrm{R}_{5}$ & 0.789 \\
\hline & $\mathrm{R}_{6}$ & 0.676 \\
\hline & $\mathrm{R}_{7}$ & 0.635 \\
\hline & $\mathrm{R}_{8}$ & 0.489 \\
\hline
\end{tabular}

The result of classical assumption test can be seen in Table 2 as follow. Meanwhile, the results of Normality Test can be viewed in P-Plot diagram and that of Heteroscedasticity test can be seen in Scatter Plot diagram in Figure 2.
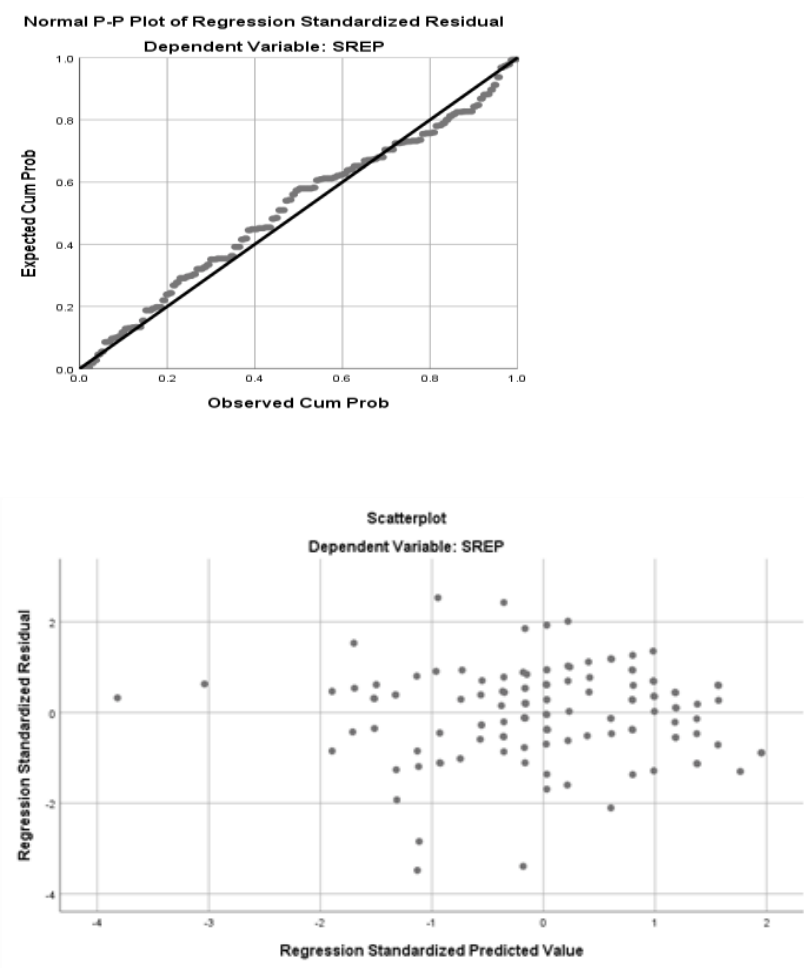

Figure 2. Test of Normality and Heteroscedasticity.

From the Figure 2 above, it can be seen that the data seems to be normal and there is no heteroscedasticity symptom. Besides, in the result of multicollinearity test, it can be seen that the value of VIF for CSR and ME variables are 1.64. This result shows that there is no multicollinearity effect among the independent variables in this study. 
Table 2. Test of Multicollinearity and Multiple Regression

\begin{tabular}{|c|c|c|c|c|c|c|c|}
\hline & \multicolumn{2}{|c|}{} & \multicolumn{2}{|}{$\begin{array}{c}\text { Standardized } \\
\text { Coefficients }\end{array}$} & & \multicolumn{2}{|c|}{ Collinearity Statistics } \\
\cline { 2 - 8 } \cline { 5 - 8 } Model & $\mathbf{B}$ & Std. Error & Beta & $\mathbf{t}$ & Sig. & Tolerance & VIF \\
\hline (Constant) & .990 & .209 & & 4.740 & .000 & & \\
\hline CSR & .383 & .060 & .448 & 6.429 & .000 & .610 & 1.640 \\
\hline ME & .373 & .060 & .432 & 6.186 & .000 & .610 & 1.640 \\
\hline
\end{tabular}

Based on the statistical test results, the multiple regression equation can be formed as follow: Rep $=0.990+0.383$ CSR $+0.373 \mathrm{ME}$.

\section{F-Test}

To conduct data analysis, several tests were conducted in form of multiple regression analysis, F-Test, and Coefficient of Determination test $\left(\mathrm{R}^{2}\right)$. F-statistics shows the value of 106.033 and the significance value of 0.00 . The means that the third hypothesis about the positive and significant effects of CSR and Marketing Ethics on Company's Reputation simultaneously could be accepted.

Table 3. F-Test

\begin{tabular}{|lr|r|r|r|r|}
\hline \multicolumn{7}{|c|}{ ANOVA $^{\mathbf{a}}$} \\
Model & $\begin{array}{r}\text { Sum of } \\
\text { Squares }\end{array}$ & df & $\begin{array}{c}\text { Mean } \\
\text { Square }\end{array}$ & F & Sig. \\
\hline 1 Regression & 19.598 & 2 & 9.799 & 106.033 & $.000^{\mathrm{c}}$ \\
\hline Residual & 11.552 & 125 & .092 & & \\
\hline Total & 31.149 & 127 & & & \\
\hline $\begin{array}{l}\text { a. Dependent Variable: MRep } \\
\text { b. Predictors: (Constant), MCSR, MEP }\end{array}$ \\
\hline
\end{tabular}

The Coefficient of Determination (CD) test aims to measure the contribution of the independent variables $(\mathrm{X})$ to the dependent one (Y). The Adjusted R-Square value is 0.623 , which has a meaning that $62.3 \%$ of variation in the Company's Reputation variable could be explained by the variables of CSR and Marketing Ethics. Meanwhile, the remaining $37.7 \%$ variation in Company's Reputation was explained by other variables out of the scope of this study.

Table 4. Coefficient of Determination

\begin{tabular}{|c|c|c|c|}
\hline Model & R Square & $\begin{array}{c}\text { Adjusted R } \\
\text { Square }\end{array}$ & $\begin{array}{l}\text { Std. Error of } \\
\text { the Estimate }\end{array}$ \\
\hline 1 & .629 & .623 & 3.03995 \\
\hline
\end{tabular}

\section{CONCLUSIONS AND IMPLICATIONS}

Among 128 respondents taking part in this study, the percentage between male and female were almost balanced. Almost all respondents were under-graduate university students while some of them were post-graduate students. Th classical assumption test that has been conducted consists of normality test, heteroscedasticity test, and multicollinearity test. According to the test results, the data used was normal, while there was no heteroscedasticity and multicollinearity effect.

The result of the first hypothesis testing showed that CSR has a positive and significant effect on Company's Reputation, with t-statistics of 6.429 and the significance value of 0.000 . This result means that the first hypothesis was accepted. This result is supported by the previous studies conducted by He [1], Hillenbrand and Money [5], Schnietz and Epstein (2005). With this result, we can conclude that CSR give means to the reputation of FMCG company in this pandemic era.

The result of the second hypothesis testing showed that Marketing Ethics has a positive and significant effect on Company's Reputation, with t-statistics of 6.186 and the significance value of 0.000 . This result means that the second hypothesis was accepted. This result is in line with the study conducted by Sasse and Trahan [27] showing that marketing ethics is proven to affect company's reputation. The implication of this result means that Marketing Ethics is one of variable that could enhance FMCG reputation in this pandemic era.

The result of the third hypothesis testing showed that CSR and Marketing Ethics simultaneously have positive and significant effects on Company's Reputation, with the regression equation as follow: $\mathrm{Rep}=0.990+0.383 \mathrm{CSR}+$ 0.373 ME. Moreover, the Adjusted $\mathrm{R}^{2}$ is 0.623 which means that $62.3 \%$ of variation in Company's Reputation can be explained by the variation in CSR and Marketing Ethics. This result means that the third hypothesis was accepted. This result is in accordance with the study conducted by Pirsch, Gupta, and Grau [11] concluding that consumers' behavior influenced by ethics and CSR can simultaneously and positively affect the company's reputation. This means that CSR and marketing ethics could have an effect on the FMCG company's reputations.

The contribution of this study to academicians is to enrich the reference on similar studies and provide the input about 
the roles of CSR and marketing ethics in company's reputation. This study can answer the inconsistencies of several studies about such relationships, such as the one conducted by Brunk [9] which mentioned that consumers' behavior is more affected by marketing ethics than business ethics.

The contribution of this study to practitioners, especially for FMCG producers is the evidence that CSR and marketing ethics provide an important role in company's reputation especially during this crisis, such as the Covid-19 pandemic. Moreover, CSR can become one of the important aspects that determine the company's reputation whenever the company falls into crisis or distress.

\section{REFERENCES}

[1] He, H. and Harris, L., 2020. The Impact of Covid19 Pandemic on Corporate Social Responsibility and Marketing Philosophy. Journal of Business Research.

[2] https://www.complianceweek.com/opinion/topethics-and-compliance-failures-of-2019/28237.article

[3] Laczniak, G.R. and Murphy, P.E., 2019. The role of normative marketing ethics. Journal of Business Research, 95, pp.401-407.

[3] https://assets.kpmg.com/content/dam/kpmg/xx/pdf/ 2017/10/kpmg-survey-of-corporate-responsibilityreporting-2017.pdf

[4] Du, Shuili., Bhattacharya, C. B., Sen, Sankar. 2007. Reaping relational rewards from corporate social responsibility: The role of competitive positioning. International Journal of Research in Marketing, 24, 224-241.

[5] Hillenbrand, C., Money, K. 2007. Corporate Responsibility and Corporate Reputation: Two Separate Concepts or Two Sides of the Same Coin?. Corporate Reputation Review, 10/4, 261-277.

[6] Tucker, L. and Melewar, T. C. 2005. 'Corporate reputation and crisis management: The threat and manageability of anti-corporatism. Corporate Reputation Review , 7/4, 377 - 387.

[7] Bhattacharya. and Sen, Sankar. 2004. Doing Better at Doing Good: When, Why, and How Consumers Respond to Corporate Social Initiatives. California Management Review, 47/1 (Fall), 9-24. Brammer, Stephen., Millington, Andrew. (2005). Corporate Reputation and Philanthropy: An Empirical Analysis. Journal of Business Ethics, 61, 29-44.
[8] https://www.unilever.co.id/news/pressreleases/2020/ unilever-ambil-peran-dalam-melindungimasyarakat-indonesia-dari-pandemi-covid-19.html

[9] Brunk, Katja H. 2010. Exploring origins of ethical company/brand perceptions: A consumer perspective of corporate ethics. Journal of Business Research, 63, 255-262.

[10] Shafer, William E., Fukukawa, Kyoko., Lee, Grace Meina. 2007. Values and the Perceived Importance of Ethics and Social Responsibility: The U.S. versus China. Journal of Business Ethics, 70/ 3, Feb, pp. 265284.

[11] Pirsch, J., Gupta, S. and Grau, S.L. 2007. A Framework for Understanding Corporate Social Responsibility Programs as a Continuum: An Exploratory Study. Journal of Business Ethics, 70, pp.125-140. http://dx.doi.org/10.1007/s10551-0069100-y

[12] Alvarez, S.A. and Barney, J.B., 2017. Resourcebased theory and the entrepreneurial firm. Strategic entrepreneurship: Creating a new mindset, 87-105.

[13] Vanhamme Joëlle (2017). Doing and publishing research in marketing ethics. Recherche et Applications en Marketing, 1- 4

[14] Vitell, S. J., Ramos, E., \& Nishihara, C. M. 2010. The Role of Ethics and Social Responsibility in Organizational Success: A Spanish Perspective. Journal of Business Ethics, 91 (4), 467-483.

[15] Gaski, John F. 1999. Does marketing ethics really have anything to say? - A critical inventory of the literature. Journal of Business Ethics , 18/ 3, Feb, 315334.

[16] Brenkert, George G. 2008. Marketing Ethics. Blackwell Publishing.

[17] Vogel, D.J. 2005. Is there a market for virtue? The business case for corporate social responsibility. California Management Review, 47, 19-45.

[18] Kotler, P. and Lee, N. (2005. Corporate Social Responsibility, Doing The Most Good for Your Company and Your Cause. John Wiley dan Sons Inc., p. 3

[19] Jamali, Dima., and Mirshak, Ramez. 2007. Corporate Social Responsibility (CSR): Theory and Practice in a Developing Country Context. Journal of Business Ethics, 72, 243-262. 
[20] Tucker, L. and Melewar, T.C. 2005. 'Corporate reputation and crisis management: The threat and manageability of anti-corporatism. Corporate Reputation Review , 7/4, 377 - 387.

[21] Walsh, Gianfranco and Beatty Sharon E. 2007. Customer-based corporate reputation of a service firm: scale development and validation. Journal of the Academic Marketing Science, 35, 127-143.

[22] Kelley, K.J., Hemphill, T.A. and Thams, Y., 2019. Corporate social responsibility, country reputation and corporate reputation. Multinational Business Review.

[23] Lange, Donald., Lee, Peggy M., and Dai, Ye. 2011. Organizational Reputation: A Review. Journal of Management, 37, 153 - 184.

[24] Peloza, J., 2006. Using corporate social responsibility as insurance for financial performance. California Management Review, 48(2), $52-72$.

[25] Gbadamosi, A., 2019. Marketing Ethics, Green and Sustainable Marketing. Contemporary Issues in Marketing: Principles and Practice, 185.

[26] Madhani, P.M., 2016. Marketing ethics: Enhancing firm valuation and building competitive advantages.

SCMS Journal of Indian Management, 13(3), 80-99.

[27] Altinbasak-Farina, I. and Burnaz, S. eds., 2019. Ethics, Social Responsibility and Sustainability in Marketing. Springer.

[28] Sasse, C. M., dan Trahan, R. T. 2007. Rethinking the new corporate philanthropy. Business Horizons, 50(1), 29-38

[29] Mitra, R. (2011). Framing the corporate responsibility-reputation linkage: The case of Tata Motors in India. Public Relations Review, July.

[30] Alwi, S.F.S., Ali, S.M. and Nguyen, B., 2017. The importance of ethics in branding: Mediating effects of ethical branding on company reputation and brand loyalty. Business Ethics Quarterly, 27(3), pp.393-422.

[31] Vitell, S.J., Rallapalli, K.C. \& Singhapakdi, A. 1993. Marketing norms: The influence of personal moral philosophies and organizational ethical culture. JAMS 21, 331

https://doi.org/10.1007/BF02894525 